\title{
Teachers' and Learners' Perceptions of Stoichiometry using POGIL: A Case Study in South Africa
}

\author{
Charles Mamombe ${ }^{1 *}$, Kgadi C Mathabathe ${ }^{1}$, Estelle Gaigher ${ }^{1}$ \\ ${ }^{1}$ University of Pretoria, SOUTH AFRICA
}

Received 1 January $2021 \cdot$ Accepted 4 July 2021

\begin{abstract}
This study explored the perceptions of teachers and learners regarding the use of Process Oriented Guided Learning Inquiry Learning (POGIL) to teach stoichiometry. A qualitative case study was carried out at two conveniently and purposively sampled township schools in Pretoria, South Africa. For this purpose, two Grade 11 physical sciences classes were identified where 48 learners and their respective teachers, who had previously been trained to teach using POGIL, gave consent to participate in the study. Data were collected using lesson observations, focus group interviews for learners and interviews for teachers. All data were transcribed and analysed with the aid of ATLAS.ti software for qualitative data analysis. The findings from the observations indicate that the learners were excited, motivated, and actively engaged in their work. They assisted one another by attempting to answer questions supported with justification. The findings from the focus group interviews indicate that the learners were excited to learn using POGIL and wished to use the method in other subjects, including mathematics. The learners had noticed improvements in their grades and understanding of abstract topics. The findings from the teacher interviews indicated that they appreciated POGIL because they found it useful in reducing misconceptions, increasing learner participation, increasing understanding and achievement, and that their learners were more engaged. The results indicate that POGIL increased learners' interest, participation and active learning, while seemingly also improving the learners' understanding of and achievement in abstract topics like stoichiometry. POGIL may be useful in increasing active learning and participation of learners which may lead to increased understanding and achievement.
\end{abstract}

Keywords: Process Oriented Guided Inquiry Learning (POGIL), active learning, interest, perceptions, reasoning

\section{INTRODUCTION}

South African (SA) learners have a history of low performance in physical sciences, especially in the chemistry section (Department of Basic Education [DoBE] Report, 2019; Mullis et al., 2016). Many difficulties in chemistry are related to stoichiometry, a major topic in chemistry learning. Stoichiometry involves the mole concept, quantities of products and reactants, and limiting reactants, to mention a few. Many learners find the topic abstract, difficult, and challenging (Department of Basic Education [DoBE] Report, 2019; Malcolm et al., 2019). Furthermore, first-year university students in SA often fail to balance equations of reactions and to identify the limiting reactant with justification (Marais \& Combrinck, 2009). Similarly, other studies also found that first-year tertiary students in SA perform poorly in stoichiometry (Potgieter et al., 2005; Potgieter \& Davidowitz, 2010). Students' weaknesses in understanding chemistry are revealed by their memorizing of formulae or definitions without understanding the underlying concepts (Marais \& Combrinck, 2009). The use of memorization by university students may be a result of the teaching approach used by their high school teachers, which has less focus on understanding (Ramnarain \& Schuster, 2014). Other SA studies reveal that most teachers use the lecture method regardless of the expectations of the new

(c) 2021 by the authors; licensee Modestum. This article is an open access article distributed under the terms and conditions of the Creative Commons Attribution License (http://creativecommons.org/licenses/by/4.0/).

\mamoocm@gmail.com (*Correspondence) $\$ Kgadi.mathabathe@up.ac.za $\$ estelle.gaigher@up.ac.za 


\section{Contribution to the literature}

- The POGIL learner-centred approach has been practised in other countries but not in South Africa where teacher-centred rote-learning is the dominant teaching approach. The results suggest that South African learners who participated in the current study were overly excited to learn science using POGIL and wished to use the method in mathematics as well.

- POGIL is often thought to waste time. This study reveals that the teachers and learners who participated in the study believed that POGIL is not time-wasting. After POGIL lessons, teachers felt that learners may not need remediation as is the case when they are taught using the lecture method.

- This study reveals that the usually passive learners participated well during POGIL intervention. This seems to indicate that POGIL improves the participation of slow learners.

inquiry-aligned Curriculum, Assessment and Policy Statement (CAPS) (Dudu, 2014; Ramnarain \& Schuster, 2014) Furthermore, in the majority of SA high schools, teachers were found to be poorly trained, inexperienced and lacking sufficient knowledge in stoichiometry (Stott, 2020). These findings from research in SA seem to point to the general deficiency of teachers and learners in stoichiometry. This deficiency in SA spans from high school up to university level, which raises serious concerns about the achievement of the expected teaching and learning outcomes. The method of instruction may also be one of the possible causes of failure in chemistry at high school, where the teaching method may negatively impact the perceptions teachers and learners have towards the subject (Mullis et al., 2016). When teachers have tried various ways to make their learners understand but still get the same low results, they may become demotivated and confused. Learners would also perceive science or chemistry as hard because they fail to understand the concepts. To assist learners, some teachers teach extra lessons in the morning before school or in the afternoon, as well as weekends or holidays. Some teachers provide learners with past examinations questions and memoranda, yet these interventions have provided little or dissatisfactory progress in terms of learner academic achievement.

The challenge of poor understanding may be addressed by active inquiry methods such as Process Oriented Guided Inquiry Learning (POGIL). POGIL is a learner-centred collaborative learning method where learners work in groups of four to six (Moog \& Spencer, 2008; Simonson, 2019), completing specially designed POGIL worksheets which guide them from the simple to the more complex concepts. During group work, learners perform roles such as manager, reader, or spokesperson where they develop $21^{\text {st }}$ century skills like teamwork. During POGIL, teachers act as facilitators of the learning process where learners are acting as the masters who are in direct contact with the learning material (Moog \& Spencer, 2008; Simonson, 2019). Over the years, POGIL has also been observed to improve understanding and achievement of abstract topics such as stoichiometry (Simonson, 2019). The carefully designed worksheets used in POGIL elicit learners' interest and attention to the information, which leads to concept development (Simonson, 2019). Literature seems to indicate that POGIL supports learning in privileged as well as in disadvantaged contexts. While the majority of the studies on the use of POGIL in science classrooms across the globe have focused on the quantitative impact in terms of academic performance, there seems to be a gap in the literature on the qualitative aspects around the effects of POGIL.

The current study explored the influence of POGIL on SA teachers' and learners' perceptions of stoichiometry. The participants were second language English speakers from disadvantaged communities studying chemistry with English as the medium of instruction. POGIL, as used in the current study, had previously been shown to improve understanding, motivation, and the achievement of learners in privileged communities in the USA (Farrell et al., 1999; Simonson, 2019). The effects of POGIL on teachers' and learners' perception of stoichiometry have not been studied in South Africa. This study, therefore, explored how using POGIL would affect South African teachers' and learners' perceptions of stoichiometry.

\section{LITERATURE REVIEW}

While stoichiometry is a major chemistry topic at high school, a low pass rate in physical sciences has been observed in SA (Department of Basic Education [DoBE] subject report, 2020; Mullis et al., 2016). The diagnostic reports from DoBE on Grade 12 examinations have, for the past few years, indicated the difficulties faced by learners in identifying limiting reactants, the calculation of moles and applying the mole ratio, among other challenges (Department of Basic Education [DoBE] Report, 2019). Previous international studies reveal that learners answered stoichiometry questions by confusing reacting mass and molar mass (Schmidt, 1990); demonstrating alternative conceptions by using mass ratio in place of mole ratio; identifying a limiting reagent as the reactant with the least number of moles; and using a 1:1 mole ratio for all substances in the equation (Dahsah \& Coll, 2007). Learners increased analytical thinking abilities and attitudes towards science, with statistical significance, after exposure to problem- 
solving activities in stoichiometry (Chonkaew et al., 2016). A study by Tingle and Good (1990) indicates that problem-solving activities helped learners to successfully solve stoichiometry questions. There was no statistically significant difference between individual problem-solving, compared to cooperative groups, in high school chemistry classes (Tingle \& Good, 1990). There were also significant disparities in stoichiometry performance between high achieving schools and low achieving schools (Agung \& Schwartz, 2007). This concurs with the findings by Stott (2020).

POGIL is a guided inquiry learning method that guides learners through learning cycles embedded in carefully designed worksheets (Process Oriented Guided Inquiry Learning, 2010; Simonson, 2019). These worksheets elicit learners' interest and attention to the information, leading to concept development (Kurumeh et al., 2012). As with the general inquiry method, POGIL emphasizes reasoning and understanding rather than memorization (Ozgelen et al., 2012; Process Oriented Guided Inquiry Learning, 2010). It also focuses on the generation of useful and applicable knowledge through investigation (Furtak et al., 2012). Inquiry has been observed to yield better results, better understanding and better motivation towards the learning of science (Harvey \& Daniels, 2009). POGIL was observed to improve active engagement and supported learners to perceive their chemistry learning as positive and beneficial (Alghamdi \& Alanazi, 2020). The participant learners in the study by Alghamdi and Alanazi (2020) developed personal relevance in the sense that they acknowledged that their classroom learning was related to their daily experiences. The learners actively participated in the class and appreciated cohesiveness (teamwork) and collaboration during the POGIL lessons. Teachers who practiced POGIL affirmed learners were more engaged and active, demonstrated better communication and teamwork skills, and improved learning outcomes when using the POGIL method $(\mathrm{Hu}$ et al., 2016). The perceived obstacles in the study by $\mathrm{Hu}$ et al. (2016) were a lack of preparation time; availability of relevant POGIL activities and pressure to complete the curriculum.

POGIL develops special inquiry skills in the learners, including communication, presentation, teamwork, critical thinking, problem-solving and reasoning and enables learners to gain a deeper understanding of the concepts (Ozgelen et al., 2012; Process Oriented Guided Inquiry Learning, 2010; Simonson, 2019). These skills are developed through collaborative work (Loo, 2013) and improve learners' scientific literacy, prepare them for future careers (McGuire \& McGuire, 2015) and may also motivate learners to develop into future researchers who are better prepared to face the world (Renee et al., 2019).

Previous studies reveal statistically significant differences in critical thinking skills and problemsolving skills in favour of the POGIL group compared to the lecture group of university chemistry students (Irwanto et al., 2018). Learners taught using POGIL had a better mathematical problem-solving ability (Muhammad \& Purwanto, 2020) and improved logical thinking ability in solving mathematical problems as compared to the learners taught using conventional learning methods (Andriani et al., 2019). Carefully structured and systematically implemented POGIL intervention helped Grade 10 science learners improve their perceptions of chemistry learning (Treagust et al., 2020).

POGIL substantially improved the pass rate of high school learners, as compared to the conventional lecture method (Walker \& Warfa, 2017). Polya's problemsolving technique was more effective than POGIL in building argumentation skills in buffer solutions (Oktaviani et al., 2020). High school learners of both genders and various American races produced fewer misconceptions in the POGIL class as opposed to traditional lecture class (Barthlow \& Watson, 2014). There was a statistically significant difference in the learning outcomes in favour of Grade 4 learners taught using POGIL compared to those taught using conventional methods (Aiman \& Uslan, 2020).

To help learners develop critical thinking and problem-solving skills, POGIL worksheets are designed with metacognition in mind (Process Oriented Guided Inquiry Learning, 2010; Simonson, 2019). Metacognition means thinking about your own thinking (McGuire \& McGuire, 2015; Simonson, 2019). The learner with metacognition has gone into the active mode of analysis, application and creating (Anderson \& Krathwohl, 2001; Bloom, 1956). Such learners know what they have learned at each stage and can identify the concepts they still need to learn or are finding difficult. During POGIL activities, the teachers ask probing questions that assist learners to justify their responses, think critically (Daubenmire et al., 2015), and develop and use high level cognitive and metacognitive skills (McGuire \& McGuire, 2015; Simonson, 2019). POGIL may be impractical with large classes as such lessons may be noisy (Simonson, 2019). POGIL can be effectively implemented by teachers trained to teach using POGIL and have good knowledge of subject matter (Simonson, 2019).

\section{METHODOLOGY}

The South African curriculum prescribes stoichiometry for Grade 11; therefore, the study was conducted with Grade 11 learners. This study was a qualitative case study exploring the perceptions of SA teachers and learners regarding the use of POGIL when teaching stoichiometry. A case study was used because such designs provide rich detailed qualitative data and insights on possible further research. It also allows for the investigation of impractical situations. The small 
sample used in the study was limited to two conveniently selected schools with two purposefully selected Grade 11 physical science classes $(\mathrm{N}=48)$ participating along with their respective teachers. For this reason, the results cannot be generalized. Case study designs are usually difficult to replicate because it depends on the participants thereof. Their perceptions may not necessarily be the same as another set of participants in similar settings. Case studies are timeconsuming and expensive, and a lot of time is needed during data collection and analysis. Qualitative data was obtained using lesson observations (observing two classes with a total of 48 learners and two teachers), two separate individual interviews with both teachers and two focus group interviews with the six learners per group. Different methods of data collection were used to ensure the trustworthiness of the data and data collection procedures as well as the ultimate findings of the study. The use of different coders, followed by discussions of the results from each data collection procedure, also strengthened the results from each method and the findings of the study.

\section{Sample}

Before the data collection commenced, a group of 25 high school teachers from a district in Pretoria attended a three-day workshop presented by an expert in the POGIL method. The workshop was a professional development initiative undertaken by a university to promote the use of POGIL in schools. Two high school teachers among those previously trained to teach using POGIL were conveniently and purposefully sampled. These teachers had undertaken to practice POGIL at their schools and consented to participate in the study. The sampled teachers were required to select one of their Grade 11 physical science classes and teach the learners during a POGIL intervention. The sample, therefore, included teacher $X$ from school $A$ and one Grade 11 physical science class $(n=22)$ and teacher $Y$ from school $B$ and one Grade 11 physical science class $(n=26)$. The schools were chosen because the teachers who were trained to teach using POGIL worked at these schools. The Grade 11 classes were chosen because they were taught by the trained teachers, and the learners in those classes were trained by their teachers to learn using POGIL. The two English-medium, multi-cultural township schools were composed of black learners of mixed gender, who were of low socioeconomic status. The 48 participating learners were those whose parents gave consent for them to participate in the study. Those who did not have or give consent were excluded from the study. At school A, learners who gave consent to participate in the study were grouped into 5 groups (4 groups composed of four learners and 1 group with six learners). The total number of participants at school A was 22 although the class had a total of 36 learners. At school B, the participating learners made 6 groups (5 groups composed of four learners and 1 group composed of six learners). There were 42 learners in this class but only 26 learners gave consent to participate. The learners who did not have consent to participate in the study were separately grouped and their work was not used as data for this study. These learners attended the lessons because stoichiometry is a prescribed topic in the annual teaching plan. Their reasons for not consenting to participate in the study were not ascertained out of respect for their rights.

\section{Data Collection Procedure}

Before commencing data collection, ethical clearance to conduct the study was granted by the relevant authorities and voluntary participation in the study was sought from the teachers, the parents of the learners and learners themselves. Before data collection, both classes at the respective schools were taught different science topics using POGIL. This was essential because learners need prior training on POGIL to understand their roles and the roles of the teacher. During the intervention, the three-hour stoichiometry lessons focusing on limiting reactants were taught over weekends, starting with school A and followed by school B the following weekend. Collecting data over weekends was agreed upon by the teachers and the learners with consideration of the duration of the intervention, which would have affected the smooth running of the schools during regular hours.

The researcher used a checklist to observe the teachers while they facilitated the learning process. The checklist addressed the teachers' activities in terms of class control, attention to the needs of learners, time management and facilitation role. It also addressed the learners' attention to instructions, excitement, participation in the group, and asking for help from the group or the teacher. After the intervention, a ten-minute focus group interview was carried out followed by the interview of the respective teacher. All interviews were audio-recorded for future transcription and analysis. The researcher opted for a ten-minute long interview to prevent learners from feeling bored by the interview soon after three hours of intervention. This could have impacted negatively on their perceptions. All qualitative data obtained from focus group and teacher interviews, as well as observations, were transcribed and coded with the assistance of ATLAS.ti software for data analysis. The software helped in keeping the coded data ready for inspection by the second coder. The system also provided accessibility of all data from the different sources for easy crystallization of the data from teachers' and learners' perceptions of using POGIL to teach stoichiometry. 


\section{Focus Group Interviews for Learners}

The focus group interviews for learners were comprised of open-ended questions that probed the learners' perceptions of both the POGIL intervention and their perception of stoichiometry before and after the intervention. The ten-minute semi-structured interview allowed the researcher to ask further questions where necessary. The questions required the learners to explain whether POGIL was a useful method to use for learning and improving their understanding. The focus group interview also probed if the learners found the method interesting, motivating, and if it had made them think more critically. The interview also addressed the extent of the participation of the learners, whether active or passive. It also addressed the learners' perception of stoichiometry, as to whether they perceived it as hard, easy, abstract, simple, or the extent to which they understood the topic after the intervention. The researcher asked all the learners one by one and allowed the learners to respond to any question they felt comfortable answering. One focus group interview was carried out soon after the intervention at each respective school. Each focus group interview was composed of six learners where each group was represented. The participating learners were purposefully and conveniently selected based on their willingness and their proficiency in English. This was done so that participant learners were able to express themselves clearly. It also helped to reduce subjectivity during data analysis.

\section{Interview for Teachers}

Each teacher was interviewed for about ten minutes at their school soon after the intervention. The openended interview allowed the interviewee to respond freely and reveal as much information as possible. The interview addressed the teachers' perceptions of POGIL as a teaching approach in relation to its effectiveness for teaching stoichiometry. The teachers could express their perceptions with regards to their learners' participation, excitement and understanding. They were asked to compare their current observations of their learners when using POGIL with the knowledge they already had about their learners when they used other teaching methods. The teachers were also asked if they would use POGIL in their future lessons and what they saw as the advantages and disadvantages of POGIL, based on their personal experience.

\section{The Teaching Intervention}

Before implementing POGIL, the science teachers were trained during a workshop by an experienced facilitator. During the teachers' workshop, the facilitator divided teachers into random groups of four. The teachers were given cards with four different roles (Manager, Spokesperson, Reader, Reflector). The teachers chose their preferred roles, as described on the cards. They were then given a worksheet about the roles in a POGIL class and asked to complete it as groups. This activity provided hands-on training for the teachers on how to train and implement a POGIL lesson. After completion of the first activity, the facilitator asked for the spokesperson to report their answers. The facilitator then concluded the first activity and gave the teachers another activity related to science. The teachers did the activity in the same way. By the end of the first day, more than five activities were completed. On the second day, the facilitator asked three volunteer teachers to facilitate the POGIL lessons, which they successfully did. The teachers felt confident and eager to practice POGIL in their respective classes.

The facilitator indicated that a few considerations should be kept in mind before using POGIL as a teaching approach. The teachers must have good subject content knowledge in the topic they want to teach. This is essential because the learners may require help with any number of questions related to the topic. The teachers need to be ready and help accordingly. Another precaution before using POGIL is that the teachers must be trained to teach using POGIL. This is essential because the teachers need to know how to respond to questions as facilitators in a learner-centred approach. Trained teachers know their roles and the roles of the learners, whom they will train before the POGIL lessons. The learners' roles translate into professional skills that they will use in their future careers, including management, teamwork, or critical thinking. The POGIL-trained teachers will be knowledgeable on how to assess their learners and facilitate a POGIL lesson.

Before the intervention, the two participant teachers who were part of the trained group of teachers, trained their learners at their respective schools and used POGIL to teach other science topics. The researcher observed some of the POGIL lessons at the teachers' respective schools to ascertain their use of POGIL and the training of the learners. During the intervention, the participant teachers used POGIL to teach their learners the topic of stoichiometry using worksheets provided by the researcher.

\section{Data Analysis}

Coding schemes were developed for data collection for each instrument used in the current study. The researcher observed the learners and teachers during the POGIL intervention, whereafter the interview of the learners sought the learners' perceptions of the POGIL method and how they perceived science before and after exposure to it. The interview of the teachers sought to find the perceptions of the teachers about the POGIL way of teaching and their perceptions of the learners' engagement and participation in stoichiometry lessons. A combination of deductive and inductive content analysis was used during coding and data analysis 
where new conceptions were allowed to emerge from the data in addition to the ones previously identified in the literature (Schreier, 2012). For assistance in data analysis, ATLAS.ti, a software for qualitative data analysis, was used. Previously identified themes such as the excitement of learners, active participation, teamwork, were loaded in the system. Such themes were then used during coding apart from other themes which emerged and were coded as they were observed. Data from the lesson observation for each school were transcribed and loaded into ATLAS.ti software for data coding. The coding which came from the observation schedule used in data collection during lessons focused on the learners' observed behaviour in terms of the level of interest, participation, excitement, among others. The coding was done for all the groups of learners who participated in the study.

In the same vein, the data from interviews of teachers and the focus group interview of learners were transcribed and coded inductively and deductively focusing on their respective perceptions about the use of POGIL in stoichiometry. The three data sources, i.e., the lesson observations, teacher interviews and learners' interviews helped triangulate the findings, for example, the level of learner participation observed during the lesson corroborated statements made by both the learners and the teachers about how POGIL encouraged engagement and active participation. The use of ATLAS.ti made the data analysis easier, faster and clear because the summary of the findings from each data collection process was collated in the system. Intercoder reliability was established by having two of the researchers separately code the same sample of data that was loaded in ATLAS.ti. The codes assigned by both coders were compared and discrepancies discussed, thus coding disagreements were resolved through discussion. The software made it easy to make quick adjustments and served as an organising tool for having all the data in one place.

\section{RESULTS}

\section{Results from the Observations}

Learners, who worked in groups, were observed during POGIL activities, as were the actions taken by the teachers during the intervention. They showed excitement by initially choosing their preferred roles for the POGIL activities. All learners actively participated in the group discussions by playing the roles of manager, spokesperson, reader, and reflector. The learners explained to each other freely and made sure that they all agreed with the answers before they wrote them down. Questions such as "do we agree?" were common. Some learners responded, "please explain ... I don't get it". When they understood the concept the learners shouted, "Ooh, I get it ... it's simple". The learners were visibly excited each time they discovered some new concepts.
They rarely asked for guidance from the teacher since they carefully followed the purpose-designed POGIL worksheets.

The teachers were observed facilitating their classes during the intervention. The teachers initially assigned learners their roles, starting with the learners' preferred roles. During the intervention, the teachers moved from one group to another asking probing questions such as, "How many moles of hydrogen atoms are needed to make one mole of water?" Such probing questions guided learners to solve the questions at hand. Sometimes the teachers found one group which had finished the activity and asked, "spokesperson please go to that group and help them solve this question". This meant that the class was one big group made up of smaller groups. At times, the teachers instructed learners to "please go back to your groups" when some had left their groups to consult other groups. The group discussions can be noisy, and the teachers often said, "managers, control the noise of your groups". The teachers spent most of the time with the slow learner groups. They did not spend much time with the other groups because they were able to solve all questions quickly. At the end of the activity, the teachers requested that the "spokesperson of each group please go to the chart and write your responses". The spokespeople wrote their groups' answers on a chart, which was then pasted on the wall by the teacher. After all responses had been written on the charts, the teacher asked the rest of the class to identify the correct responses. The teachers asked some learners from groups who had correctly answered, to explain difficult questions to the whole class.

\section{Results from Interview of the Teachers}

The teachers showed awareness of the POGIL way of teaching. During the interview, they explained that POGIL is a method where we "use group work and learners ... help each other". Both teachers acknowledged that during POGIL, learners "help each other in the process and solve even the difficult questions." The teachers appreciated POGIL which they commended as "a wonderful and easy method", which "gives time to attend to the slow learners" and that the "fast learners will do a lot of work" on their own. They indicated that the slow learners are less noisy and gave sound reasons for their ideas and that the "slow learners also participated actively".

Both teachers noted that their learners were "very excited to use POGIL". Some learners even asked the teachers to always use POGIL because the learners said "POGIL makes them to be free and active". The learners are free to talk and "everyone is alert and participating actively," unlike during lectures where all learners are supposed to be quiet, and many even end up sleeping during lessons. The teachers reported that some learners asked them to tell the mathematics teacher "to teach them using POGIL". This suggests that the learners are "already motivated to learn using POGIL in other subjects". It 
appears the learners had developed metacognition and were aware of a method that could help them understand mathematics better.

The teachers were aware that the first activities are supposed to be "simple, real-life experiences". This helps learners to understand the concepts before they apply them to the real subject content and that, when doing "difficult topics, they are passive and need a lot of help". This suggests that the worksheet must not be too hard because the learners will become disengaged. Likewise, the teachers noted that worksheets should not be too easy either as "each learner will be working quietly on their own." Overly easy activities do not support POGIL because learners will be working individually, instead of engaging each other in the group. Therefore, the worksheets need to strike a balance. The teachers know the needs of their learners and acknowledged that the POGIL worksheets used during the intervention were neither too easy nor too hard. This kept the learners engaged throughout the intervention.

The teachers demonstrated their awareness of the POGIL way of teaching by "guiding the learners" as well as "checking if the learners had problems and if they were working in groups". The teachers provided advice, direction and motivation to the groups as they moved around the class. They acted as facilitators, unlike what is done during the lecture method. This view is in line with the POGIL philosophy that the approach must be learner-centred and not teacher-centred.

Both teachers acknowledged that when they teach using POGIL their "learners perform much better than when I use lecture method". They wished to "use POGIL in the whole syllabus" if they have all the worksheets because "POGIL encourages teamwork and more participation". The teachers also noted that during POGIL, the learners "cannot go outside of what they are learning, and they are kept busy." This suggests that the teachers appear to be happy with POGIL as a teaching method in their classes because it kept the learners engaged on their work.

The teachers acknowledged that "stricter control is needed during POGIL than during lecture method" because the learners can "make so much noise which disturbs other groups and other classes". It is partly because, during POGIL discussions, the learners "cannot just bring the answer [sic] without justification". They argue to support their answer until consensus is reached. If they do not agree, they ask other groups or the teacher. The teachers commented that "POGIL helps to reduce misconceptions" since learners base their answers on reasoning.

One of the teachers suggested that she "initially thought POGIL was time consuming" but with experience discovered that what "my learners do with POGIL will be permanent". They therefore felt that less repetition or revision would be required. The teacher noted that "with lecture method" she "will repeat it like another three or four times" and still the learners will not perform as they do when they learn using POGIL. This teacher seems to have analysed the time consumed per topic and not per lesson. The other teacher said POGIL is "very time consuming but at the end of the day you are able to do a lot." The second teacher might not have viewed POGIL with the idea which the first teacher got.

\section{Results from the Focus Group Interview of Learners}

The learners acknowledged that they were familiar with POGIL by defining it as a method where learners "work in groups discussing classwork". They noted that POGIL uses "examples which give clues on how to approach particular questions" which makes science "easier" by using "real life" examples. The learners indicated that POGIL is an "interesting and funny" method used to "learn difficult topics". The learners observed that POGIL was used when teaching abstract topics. So, they associate it with difficult topics.

The learners noticed that in POGIL they "are free to talk about many things and help each other." They were happy that "no one hears" their "wrong answers" except those in their group. They commended POGIL because they "help each other without laughing at one another." This suggests that some learners may be afraid to participate in class for fear of being laughed at, unlike in POGIL where they will be in small groups. The learners commended POGIL as "good because we understand" since they were required to "think of why the answer is correct". The learners were aware that they must use reasoning to find an answer. Arguments tend to develop when learners start giving reasons for their response, resulting in the noisy classes that are peculiar to POGIL.

The learners said that "the POGIL method makes science to be easy [sic]" although it had always been perceived as a difficult subject. The learners also felt confident that they could now "answer hard questions". "The POGIL method is easy because we start with easy activities," one of the learners noted. It appears as if learners who are taught using POGIL develop metacognition since they can describe the methodology of how they are taught and the level of questions they can answer. The learners commented that "in the past, science was difficult to understand" but now it is easy because of the POGIL method. They also indicated that they "have been made to be clever" and can now think before writing down the answer "instead of guessing". POGIL helped the learners "to understand science better" and improved their "reasoning capacity". It seems POGIL improves learners' critical thinking and ability to tackle complex multi-step questions.

The learners were also able to link science with daily life experiences like "wearing two shoes, two socks, one pants [sic], one shirt" which is a "ratio like two moles of hydrogen reacting with one mole of oxygen" to produce two moles of water. They could reason and assess that one "cannot put on three shoes at the same time". This means 
that the learners have developed reasoning and understanding because of exposure to POGIL methodology. The learners appeared to be thinking critically which is necessary for problem-solving.

The learners expected better marks after being taught using POGIL because they now know better and "understand and think about the answer" before writing it down. The learners "can now reason and know how to find the limiting reactant". The learners recognized that it helped them "understand all things". The learners appreciated the "step-by-step" teaching done using POGIL, which they felt helped them understand science better. The students believed that their marks would be high enough for them to enrol in "engineering because by using POGIL we will pass" or "do medicine ... or become a dentist because POGIL will give us high passes". The method seemed to have developed confidence in the learners, to the extent that they now have metacognition and are focused on their future careers. The learners wished to "use POGIL in mathematics" so that their "marks will go up". They noticed that "mathematics has a lot of measurements and objects" and it is possible to use POGIL in mathematics, acknowledging that "the mathematics marks are the lowest".

\section{DISCUSSIONS}

Both the POGIL-trained teachers noted that their learners participated actively and were not disengaged during the intervention, unlike when they used the lecture method. This was in agreement with the previous findings by Barthlow and Watson (2014). They noted that the POGIL worksheet used was neither too easy nor too hard and this allowed learners to remain focused on the activities because the work was understandable. This was in line with the POGIL recommendations indicated by Simonson (2019). Both teachers played the role of facilitator during the intervention, allowing for a learnercentred approach as opposed to a teacher-centred approach. The teachers directed learners by asking questions to guide but not giving them answers like in the lecture method. Both teachers noted that POGIL has noisy classes since learners argue to justify their answers. These observations agreed with previous findings available in the literature of $\mathrm{Hu}$ et al. (2016). One teacher said POGIL is time-consuming because of the time it takes to prepare and complete the lesson. This is in line with previous findings by $\mathrm{Hu}$ et al. (2016). The other teacher contradicted that view by arguing that what they teach using POGIL will be permanent and that less repetition would be required, making it less timeconsuming.

Overall, both teachers felt that POGIL is a good teaching approach and promised to continue teaching using POGIL because they witnessed better participation of learners, active engagement, and improved understanding of science. This agrees with the study by Mullis et al. (2016). The teachers acknowledged that POGIL reduces misconceptions in agreement with the study by Oktaviani et al. (2020). They both wished to have POGIL worksheets for use in all the science topics, which agrees with the findings by $\mathrm{Hu}$, et al. (2016). They also recommended that POGIL worksheets be made available for other subjects since their learners were excited to learn using POGIL as opposed to the lecture method.

The results from the interview suggest that the learners noticed that POGIL activities are structured to progress from easy, familiar concepts to more difficult concepts. The learners commended POGIL for making science easy, interesting, funny, and using real-life examples which helped them understand science better. The learners acknowledged that POGIL enabled them to increase their reasoning capacity and improve their argumentation abilities as they supported their opinions before peers. This agrees with the findings by Oktaviani et al. (2020). Learners noticed that they must think about their answer before presenting it to the group. This suggests that with the POGIL method, learners develop metacognition, which agrees with the findings by McGuire and McGuire (2015). The learners also noticed that POGIL is used mainly in abstract topics where indepth critical thinking and reasoning are important for understanding the concepts. The use of real-life examples suggests that science is not isolated from daily experiences thereby making it understandable to the learners.

The learners acknowledged improvement in their performance and understanding in science, which agrees with Ozgelen et al. (2012) They attributed the improvement to the step-by-step procedures used in POGIL that developed their understanding. This suggests that the learners increase their critical thinking skills in arguments and develop other process skills such as communication, management, teamwork and problem-solving, information processing, and assessment. The learners further assessed themselves and felt that they will qualify to study medicine and engineering because of their improved performance and understanding of science. This is in line with the findings by Farell et al. (1999). They wished to be taught mathematics using POGIL because they noticed they had low marks in that subject. Through their exposure to POGIL, the learners developed metacognition and other process skills. They attribute this development to the use of POGIL in their science classes.

\section{CONCLUSIONS AND RECOMMENDATIONS}

Great care was taken in the collection and analysis of data during this study. However, we acknowledge the short observation period and the small sample as limitations. Furthermore, the authors acknowledge that 
there could have been other factors that may have affected the teachers' and the learners' perceptions apart from the intervention. Despite these limitations, the study provided valuable insights into how POGIL enhances South African learners' attitudes towards the topic of stoichiometry. Another limitation of case study design is the subjective judgement of the researcher which may have influenced the study (McLeod, 2019). For this study, subjectivity was reduced by collecting and triangulating various forms of data and using an independent coder to establish intercoder reliability.

Both the learners and the teachers who participated in the study demonstrated their interest in using POGIL in stoichiometry. They commended POGIL for improving learner participation, motivation, excitement, focus-driven and active involvement. The learners perceived POGIL as a method that made science easy. The learners improved their metacognition since they attributed the improvements to the use of POGIL and requested to be taught mathematics using POGIL. The teachers commended POGIL for facilitating the active engagement of learners, who banded together to answer questions through reasoning, while giving sound justification for their opinions. However, its use in classrooms may be restricted by the availability of lesson time and the availability of suitably prepared POGIL worksheets in various topics.

The results suggest that POGIL instruction elicits learners' interest and participation, which leads to their understanding and reasoning. The use of POGIL seems to be a possible solution to the low pass rate of South African learners in physical science. This could be true because both the teachers and learners positively perceived POGIL as a good teaching method in stoichiometry. However, using the treatment on a larger sample may be more conclusive as to the effectiveness of POGIL on learners' perceptions as related to their understanding and reasoning in stoichiometry. Our findings suggest that teachers should consider POGIL or other learner-centred methods in the teaching of abstract and difficult topics, as the expected positive perceptions may lead to enhanced understanding.

Author contributions: All authors have sufficiently contributed to the study, and agreed with the results and conclusions.

Funding: This study was funded by the National Research Foundation, South Africa.

Acknowledgements: The authors would like to acknowledge the grade 11 learners and teachers of the two participating schools for consenting to being part of this study.

Declaration of interest: No conflict of interest is declared by authors.

\section{REFERENCES}

Agung, S., \& Schwartz, M. S. (2007). Students' understanding of conservation of matter, stoichiometry and balancing equations in Indonesia. International Journal of Science Education,
29, (13), 1679-1702. https://doi.org/10.1080/ 09500690601089927

Aiman, U., \& Uslan, S. (2020). The improvement of science learning outcomes of primary school students through the model of pogil supplemented with the student worksheet. In Proceedings of the 5th Progressive and Fun Education International Conference (PFEIC 2020) (Advances in Social Sciences, Education and Humanities Research Series).

https:/ / doi.org/10.2991/assehr.k.201015.028

Alghamdi, A. K., \& Alanazi, F. H. (2020). Processoriented guided-inquiry learning in Saudi secondary school chemistry instruction. Eurasia Journal of Mathematics, Science and Technology Education, 16(12) em1920. https:/ / doi.org/10.29333 / ejmste/9278

Anderson, A., \& Krathwohl, D. (2001). A Taxonomy for learning, teaching and assessing: A revision of Bloom's taxonomy of educational objectives (2nd Edition). Allyn and Bacon.

Andriani, S., Nurlaelah, E., \& Yulianti, K. (2019). The effect of Process Oriented Guided Inquiry Learning (POGIL) model toward students' logical thinking ability in mathematics. Journal of Physics: Conference Series, 1157(4). https://doi.org/10.1088/17426596/1157/4/042108

Barthlow, M. J., \& Watson, S. B. (2014, May 11). The effectiveness of process-oriented guided inquiry learning to reduce alternative conceptions in secondary chemistry. School Science and Mathematics, 114(5), 246-255. https:/ / doi.org/10.1111/ssm.12076

Bloom, B. S. (1956). Taxonomy of Education Objective, Handbook 1: Cognitive Domain. David Mckay Co Inc.

Chonkaew, P., Sukhummek, B., \& Faikhamta, C. (2016). Development of analytical thinking ability and attitudes towards science learning of grade-11 students through science technology engineering and mathematics (STEM education) in the study of stoichiometry. Chemistry Education Research and Practice, 17, 842-861. https://doi.org/10.1039/ C6RP00074F

Dahsah, C., \& Coll, R. (2007). Emiratii high school students' understandings of stoichiometry and the influence of metacognition on their understanding. Research in Science and Technological Education, 227241. https:/ / doi.org/10.1080/02635140802037393

Daubenmire, P. L., Bunce, D. M., Draus, C., Frazier, M., Gessell, A., \& van Opstal, M. T. (2015). During POGIL implementation the professor still makes a difference. Journal of college science teaching, 44(5), 72-81.

https://doi.org/10.2505/4/jcst15_044_05_72 
Department of Basic Education [DoBE] Report. (2019). National senior certificate diagnostic report. Government Printing Works. www.info.gov.za

Department of Basic Education [DoBE] subject report. (2020). National senior certificate examination: School subject report. www.info.gov.za

Dudu, W. T. (2014). The changing roles of South African Natural Sciences teachers in an era of introducing a "Refined and Repackaged" curriculum. Journal of Science Education, 7(3), 547-558. https://doi.org/ 10.1080/09751122.2014.11890216

Farrell, J. J., Moog, R. S., \& Spencer, J. N. (1999). A guided inquiry general chemistry course. Journal of Chemical Education, 76, 570-573. https://doi.org/ 10.1021/ed076p570

Furtak, E. M., Seidel, T., Iverson, H., \& Briggss, D. C. (2012). Experimental and quasi-experimental studies of inquiry-based teaching: A meta-analysis. Review of Educational Research, 82, 300-329. https:/ / doi.org/10.3102/0034654312457206

Harvey, S., \& Daniels, H. (2009). Inquiry approach versus coverage approach: Comprehension and Collaboration. Heinemann.

Hu, H. H., Kussmaul, C., Knaeble, B., Mayfield, C., \& Yadav, A. (2016). Results from a survey of faculty adoption of process oriented guided inquiry learning (POGIL) in computer science. Conference on Innovation and Technology in Computer Science Education (pp. 186-191). ACM. https:/ / doi.org/10.1145/2899415.2899471

Irwanto, S. A., Rohaeti, E., \& Prodjosantoso, A. K. (2018). Promoting critical thinking and problem solving skills of preservice elementary teachers through process-oriented guided-inquiry learning (POGIL). International Journal of Instruction, 11(4), 777-794. https:/ / doi.org/10.12973/iji.2018.11449a

Kurumeh, M. S., Jimin, N., \& Mohammed, A. S. (2012). Enhancing senior secondary students' achievement in algebra using inquiry method of teaching in Onitsha Educational Zone of Anambra State, Nigeria. Journal of Emerging Trends in Educational Research and Policy Studies, 3(6), 863-868. https://doi.org/10.10520/EJC132382

Loo, J. L. (2013). Guided and team-based learning for chemical information literacy. Journal of Academic Librarianship, 39(3), 252-259. https://doi.org/ 10.1016/j.acalib.2013.01.007

Malcolm, S. A., Mavhunga, E., \& Rollnick, M. (2019). The validity and reliability of an instrument to measure physical science teachers' topic specific pedagogical content knowledge in stoichiometry. African Journal of Research in Mathematics, Science and Technology Education, 23(2), 181-194. https:/ / doi.org/10.1080/18117295.2019.1633080
Marais, F., \& Combrinck, S. (2009). An approach to dealing with difficulties undergraduate chemistry students experience with stoichiometry. South African Journal of Chemistry, 62, 88-96. http:/ /journals.sabinet.co.za/sajchem/

McGuire, S. Y., \& McGuire, S. (2015). Teach students how to learn. Stylus publication. https:/ / styluspub.press warehouse.com/uploads/51820e4712ebd7d78e479 bb7dc2a216e5e

McLeod, S. A. (2019, August 3). Case study method. https://doi.org/10.7936/K7PN93HC

Moog, R., \& Spencer, J. (2008). POGIL: Process Oriented Guided Inquiry Learning. ACS Symposium series 994. American Chemical Society.

Muhammad, M., \& Purwanto, J. (2020). The effect of process oriented guided inquiry learning. Journal of Physics: International Conference on Innovation in Research, 1469, 012171. https://doi.org/10.1088/ 1742-6596/1469/1/012171

Mullis, I. V., Martin, M. O., Foy, P., \& Hooper, M. (2016). TIMSS 2015: International results in mathematics. TIMSS and PIRLS International Study Centre. http:/ / timssandpirls.bc.edu/timss2015/internatio nal-results

Oktaviani, N. K., Prastika, A. P., Fajaroh, F., \& Suharti, S. (2020). Incorporation of polya's problem solving into process guide inquiry in learning buffer solution. In AIP Conference Proceedings, 2215(1), 20016. https:/ / doi.org/10.1063/5.0000692

Ozgelen, S., Yilmaz-Tuzun, O., \& Hanuscin, D. L. (2012). Exploring the development of preservice science educators' views on the nature of science in inquiry-based laboratory instruction. Journal of Research in Science Education, 43(4), 1551-1570. https: / / doi.org/10.1007/s11165-012-9321-2

Potgieter, M., \& Davidowitz, B. (2010). Grade 12 achievement rating in new national senior certificate as indication of preparedness for tertiary chemistry. South African Journal of Chemistry, 63, 7582. http:/ /journals.sabinet.co.za/sajchem/

Potgieter, M., Rogan, J. M., \& Howie, S. (2005). Chemical concepts inventory of grade 12 learners up to foundation year students. African Journal of Research Mathematics, Science and Technology Education, 9(2), 121-134. https:/ / doi.org/10.1080/10288457.2005.10740583

Process Oriented Guided Inquiry Learning. (2010). What is process oriented guided inquiry learning (POGIL)? http:/ / www.pogil.org

Ramnarain, U., \& Schuster, D. (2014). The pedagogical orientations of South African physical sciences teachers towards inquiry or direct instructional approaches. Research in Science Education, 44(4), 627650. https:/ / doi.org/10.1007/s11165-013-9395-5 
Renee, S., Lantz, J. M., \& Ruder, S. M. (2019). The process. In S. R. Simonson (Ed.), An introduction to process oriented guided inquiry learning for those who wish to empower learners (pp. 42-68). Stylus publishing.

Schmidt, H.-J. (1990). Secondary school students' strategies in stoichiometry. International Journal of Science Education, 12(4), 457-471. https://doi.org/ $10.1080 / 0950069900120411$

Schreier, M. (2012). Qualitative content analysis in practice. Sage Publishers.

Simonson, S. R. (2019). An introduction to Process Oriented Guided Inquiry Learning for those who want to empower learners. Stylus Publishing.

Stott, A. (2020). Influence of context on stoichiometry conceptual and algorithmic subject matter knowledge among South African physical sciences teachers. Journal of Chemical Education, 97(5), 1239. 1246.

https:/ / doi.org/10.1021/acs.jchemed.0c01459
Tingle, J. B., \& Good, R. (1990). Effects of cooperative grouping on stoichiometric problem solving in high school chemistry. Journal of Research in Science Teaching, 27(7), 671-683. https://doi.org/10.1002/tea.3660270707

Treagust, D., Qureshi, S., Vishnumolakala, V., Ojeil, J., Mocerino, M., \& Southam, D. C. (2020). Processoriented guided inquiry Learning (POGIL) as a culturally relevant pedagogy (CRP) in Qatar: a perspective from grade 10 chemistry classes. Research in Science Education, 50, 813-831. https: / / doi.org/10.1007/s11165-018-9712-0

Walker, L., \& Warfa, A.-R. M. (2017). Process oriented guided inquiry learning (POGIL) marginally effects student achievement measures but substantially increases the odds of passing a course. Public Library of Science (PLOS), 12(10), e0186203. https://doi.org/10.1371/journal.pone.0186203

\section{http://www.ejmste.com}

